\title{
Rimantas Miknys
}

Instytut Historii Litwy

\section{Czy naprawdę unia została wykreślona z projektów Litwy nowoczesnej w końcu XIX - na początku XX wieku?}

\begin{abstract}
Zarys treści
W artykule podjęto próbę krytycznej oceny tezy funkcjonującej w historiografii litewskiej, a częściowo także polskiej, że idea unii obu państw została wyeliminowana z projektów litewskiego ruchu narodowego ukształtowanych w końcu XIX i na początku XX w. Wyniki analizy ukazują potrzebę badań koncepcji federalizmu litewskiego, ze szczególnym uwzględnieniem kwestii wpływu na nią unii polsko-litewskiej.
\end{abstract}

\begin{abstract}
The article offers a critical assessment of the deeply entrenched view in Lithuanian and Polish historiography that the idea of the (Lublin) Union was erased from the Lithuanian statehood projects created within the Lithuanian national movement in the late nineteenth-early twentieth centuries. Summarising the critical assessments made against this idea, several theses were formulated based on which further research could be conducted that could explain the effects of the Union on the formation and development of "Lithuanian federalism".
\end{abstract}

Słowa kłuczowe: idea unii polsko-litewskiej (lubelskiej), litewski ruch narodowy, projekty państwowości Litwy, „federalizm litewski”, historiografia litewska a polska

Keywords: idea of the (Lublin) Union, Lithuanian national movement, Lithuanian statehood projects, "Lithuanian federalism", Lithuanian and Polish historiography

Przez długi czas zarówno w historiografii polskiej, jak i litewskiej żywe było przekonanie, że litewski ruch narodowy uznawał unię jako projekt polityczny za przeżytek, dla którego nie było miejsca, przynajmniej od czasów publikacji pisma „Aušra” (1883-1886). Należy podkreślić, że krajowcy, Michał Römer czy Albin Józef Herbaczewski, rozważający i omawiający możliwości odrodzenia unii w latach 1905-1915, nie byli uznawani za bezpośrednich wyrazicieli 
myśli politycznej litewskiego ruchu narodowego ${ }^{1}$. Co prawda Piotr Łossowski już w wolnej Polsce, precyzując swoją koncepcję litewskiego ruchu narodowego, opracowaną w latach 1966-1990, mówił o dwóch drogach litewskiego odrodzenia na początku XX w. Pierwszą łączył z Jonasem Basanavičiusem i „Aušrą”, drugą zaś - nawiązującą do unii - $\mathrm{z}$ wówczas już nieco zapomnianym bp. Antonim Baranowskim (Antanasem Baranauskasem). Drugą - unijną drogę - ocenił jako koncepcję przegraną i szybko zapomnianą ${ }^{2}$.

Podobne oceny można spotkać również w najnowszej historiografii litewskiej. Moim zdaniem taki sam pogląd wyrazili również w tym samym czasie Antanas Kulakauskas i Egidijus Aleksandravičius ${ }^{3}$. Jednak niespodziewanie w 2012 r. Aleksandravičius, odwołując się do polskich historyków (Józefa Lewandowskiego, Krzysztofa Grygaitisa, Juliusza Bardacha, Jerzego Ochmańskiego, Piotra Łossowskiego, Jana Jurkiewicza) $)^{4}$, którzy badali idee nowoczesnego federalizmu polskiego oraz wyjaśniali, w jakim zakresie i jaki sposób były powiązane z ideą unii, podjął skuteczną próbę znalezienia w litewskim federalizmie z XIX - początku XX w. nurtu powiązanego $\mathrm{z}$ „dawną" unią ${ }^{5}$. Po analizie historiografii litewskiego odrodzenia narodowego, dokonaniu przeglądu zawartej w niej faktografii i ocenie wniosków $\mathrm{z}$ badań, stwierdził, że federalistyczne perspektywy Litwy w omawianym okresie są

${ }^{1}$ Krajowość - tradycje zgody narodów $w$ dobie nacjonalizmów. Materiały z międzynarodowej konferencji naukowej w Instytucie Historii UAM w Poznaniu (11-12 maja 1998), red. J. Jurkiewicz, Poznań 1999; J. Sawicki, Michał Römer a problemy narodowościowe na ziemiach byłego Wielkiego Księstwa Litewskiego, Toruń 1998; Z. Solak, Między Polską a Litwą. Życie i działalność Michała Römera 1880-1920, Kraków 2004, s. 59-235; R. Miknys, Stosunki polsko-litewskie w wizji krajowców, „Zeszyty Historyczne” (Paryż) 1993, nr 104, s. 123-129; idem, Mykolo Römerio Lietuvos valstybingumo koncepcija ir pastangos ja igyvendinti 1911-1919 metais, w: Lietuviu atgimimo istorijos studijos, t. 13: Mykolas Römeris, Vilnius 1996, s. 88-113; V. Sirutavičius, Dvi lietuviu tautinio atgimimo interpetacijos (Mykolas Römeris ir Juozapas Albinas Herbačiauskas), w: Lietuvių atgimimo istorijos studijos..., t. 13, s. 54-79.

2 P. Łossowski, Dwie drogi odrodzenia kulturalnego i narodowego Litwinów: Baranauskas i Basanavičius, „Studia z Dziejów Rosji i Europy Środkowo-Wschodniej” 31, 1996, s. 149-155.

3 E. Aleksandravičius, A. Kulakauskas, Caru valdžioje. Lietuva XIX amžiuje, Vilnius 1996 (wyd. pol.: Pod władza carów. Litwa w XIX wieku, tłum. B. Kalęba, Kraków 2003); Lietuvos istorija, t. 10, cz. 1: Nepriklausomybe (1918-1940), red. Č. Laurinavičius, Vilnius 2013, s. 68-86.

4 J. Lewandowski, Federalizm. Litwa i Białoruś w polityce obozu belwederskiego (XI 1918 - IV 1920), Warszawa 1962; K. Grygaitis, Polskie idee federacyjne i ich realizacja w XIX i XX w., Częstochowa 2001; J. Bardach, Krajowcy, federaliści, inkorporacjoniści, w: idem, O dawnej i niedawnej Litwie, Warszawa 1988, s. 261-270; J. Ochmański, Historia Litwy, Wrocław 1982; idem, Litewski ruch narodowo-kulturalny w XX wieku, Białystok 1965; P. Łossowski, Po tej i tamtej stronie Niemna. Stosunki polsko-litewskie 1883-1939, Warszawa 1985; J. Jurkiewicz, Demokraci wileńscy w latach 1905-1914 (Zarys działalności politycznej), „Acta Baltico-Slavica” 18, 1983, s. 157-173; idem, Rozwój polskiej myśli politycznej na Litwie i Białorusi w latach 1905-1922, Poznań 1983.

${ }^{5}$ E. Aleksandravičius, Unijos šešèlyje, arba federalizmas lietuviu Atgimimo politinèje vaizduotèje (XIX a. pabaiga - XX a. pradžia), w: Lietuva ir Lenkija XX amžiaus geopolitinejje vaizduotejje, Kaunas 2012, s. 11-33. 
„przykryte” rozpowszechnioną w litewskiej historiografii nacjonalistyczną metodologią, unikającą takich pytań jak: „Czy pod koniec XIX - na początku XX w. na horyzoncie politycznym litewskiego odrodzenia pojawiły się oznaki federalizmu? Czy wizje federalistyczne były jedynie środkami podyktowanymi przez warunki historyczne, czy ostatecznym celem przyszłości politycznej? Jeżeli istniały - jakie miejsce $\mathrm{w}$ ówczesnym pejzażu przyszłości politycznej zajmowały stosunki lub ewentualne powiązania federacyjne $\mathrm{z}$ Polską? [...] Wreszcie, czy litewskie wizje federalizmu różniły się od myśli polskiej? Te i inne pytania nadal czekają na historyków i badaczy myśli politycznej, chętnych do udzielenia na nie odpowiedzi"'. $\mathrm{Z}$ drugiej strony, w uwagach końcowych do swojego artykułu, opierającego się na traktacie (memoriale) Michała Römera z 1915 r. Litwa wobec wojny ${ }^{7}$, omawiając różne ówczesne perspektywy federalistyczne Litwy, obecne w kręgu litewskich polityków i szerszych warstw społecznych, badacz podkreśla, iż „z poznania rozważań politycznych Römera wynika, że wielu poważnych tekstów jeszcze nie przeczytano lub przeczytano bardzo powierzchownie, selektywnie"8. Właśnie te przywołane uwagi Aleksandravičiusa zachęciły mnie do analizy tytułowego problemu. Tym bardziej że we wspomnianym artykule badacz skonstatował, że również mnie nie udało się wyzwolić z sideł litewskiego nacjonalizmu metodologicznego w rozważaniach o związkach między tradycją polityczną Wielkiego Księstwa Litewskiego i litewskimi programami odrodzenia. Według niego: „Najbardziej przejrzysta interpretacja została zawarta w artykule Rimantasa Miknysa z 2009 r. »Tradycje państwowości Wielkiego Księstwa Litewskiego w programie litewskiego ruchu narodowego: aspekt teoretyczny i praktyczny «? ${ }^{9}$. Jednak również w tej publikacji zwolennicy idei federalizmu nie zdobyli prawa do samodzielnej egzystencji, tj. konceptualnie pozostali w okopach litewskiej historiografii. Zostały one wzmocnione, pogłębione, jednak ich topografia teoretyczna nie uległa zmianie"10.

W niniejszym tekście na pewno nie będę dokonywać teoretycznej reinterpretacji wyjaśnień zawartych w przywołanym wyżej artykule. Odniosę się jedynie do niektórych zawartych w nim uwag, przedstawię fakty, interpretując je w kontekście tematu wystąpienia: czy naprawdę koncepcja unii została wykreślona z projektów Litwy nowoczesnej w końcu XIX i na początku XX w.?

Nie będę też omawiał zmian sposobu objaśniania polsko-litewskich związków unijnych w okresie powstań w XIX w. i później, ponieważ poświęciłem

\footnotetext{
${ }^{6}$ Ibidem, s. 12-13 (jeżeli nie zaznaczono inaczej, tłumaczenia są dziełem autora).

7 Litwa wobec wojny. Poufny memoriat Michała Römera $z$ sierpnia 1915, oprac. W. Sukiennicki, „Zeszyty Historyczne” 1970, 17, s. 56-127.

8 E. Aleksandravičius, op. cit., s. 33.

9 Chodzi o artykuł: R. Miknys, Lietuvos Didžiosios Kunigaikštystès valstybingumo tradicija lietuviu tautinio judejjimo programoje: teorinis ir praktinis aspektai, w: Lietuvos Didžiosios Kunigaikštijos tradicija ir tautiniai naratyvai, oprac. A. Bumblauskas, G. Potašenko, Vilnius 2009, s. 117-143.

${ }^{10}$ E. Aleksandravičius, op. cit., s. 14-15.
} 
temu osobny artykuł ${ }^{11}$. Rozpocznę zaś od przywołania stanowiska względem unii Mikołaja Akielewicza (Mykolasa Akelaitisa), walczącego w powstaniu styczniowym, gdyż w pewnym sensie odnotowuje on związek między powstańcami oraz pismami „Aušra” i „Varpas”. Po wyjeździe do Paryża Akielewicz, unionista, był swoistym liderem wychodźstwa z Litwy, jedną z najważniejszych osób kształtujących stanowisko tego środowiska również w okresie popowstaniowym. Nadal stan on na stanowisku ogłoszonym przez Komitet Narodowy w czasie powstania: „Nie ma Polski bez Litwy i Rusi, jak nie ma jej bez Korony”" przemawiając w szkole Batignolles w Paryżu w imieniu Litwy podczas obchodów rocznicy zawarcia unii lubelskiej, scharakteryzował ten związek jako drogowskaz w działalności i sparafrazował powyższe hasło tak:

Jeszcze Litwa nie zginęła,

Póki Polska żyje;

Jeszcze Polska nie zginęła,

Póki my żyjemy... ${ }^{13}$

Z biegiem czasu, w latach 60.-70. XIX w., stanowisko Akielewicza w kontekście idei wyzwolenia Polski stawało się coraz bardziej autonomiczne. Nie rezygnując z poglądów unijnych, nieco inaczej zaczął on interpretować koncepcję litewskości. Obok dawnej, klasycznej jej treści, zaczął z nią łączyć wrażliwość, przychylność wobec języka litewskiego i kultury etnicznej. Świadczy o tym jego korespondencja z Józefem Ignacym Kraszewskim, Adamem Honorym Kirkorem, Wiktorem Korotyńskim, Oskarem Kolbergiem, a także jego prace leksykograficzne ${ }^{14}$. Akielewicz rozumiał znaczenie języka dla kształtowania się nowoczesnego społeczeństwa. W 1886 r. z jego inicjatywy powołano towarzystwo „Želmuo”"15. Faktycznie było ono jedną z nielicznych za granicą organizacji, które reprezentowały rozwijający się na Litwie ruch narodowy. Właśnie ono na przełomie XIX i XX w. było blisko związane ze środowiskiem wydającym pismo „Varpas”. W jego działalności widoczne są ślady tradycji państwowości Wielkiego Księstwa Litewskiego oraz próby jej połączenia z nowymi dążeniami. Od samego początku podkreślało ono litewski aspekt narodowy, który początkowo nie stał jednak w sprzeczności

11 R. Miknys, Lietuvos Didžiosios Kunigaikštystès valstybingumo tradicija..., s. 117-143.

12 J. Borejsza, Emigracja polska po powstaniu styczniowym, Warszawa 1966, s. 234.

${ }^{13}$ Lietuviu kultūros veikèjų laiškai J.I. Kraševskiui, wyd. B. Genzelis, Vilnius 1992, list M. Akielewicza do J.I. Kraszewskiego, 17 VIII 1869, s. 129.

14 Ibidem, s. 64-65, 70, 91, 93; A. Туlа, Связи Микалоюса Акелаитиса с польскими культурными и политическими деятелями, w: Zwiazki rewolucjonistów polskich i rosyjskich w XIX w. Materiały sesji naukowej, Poznań, 12-14 listopada 1970, przyg. W. Śliwowska, Wrocław 1972, s. 171-179; J. Kudirka, Mikalojaus Akelaičio (1829-1887) socialinés pažiūros, „Lietuvos aukštųjų mokyklų mokslo darbai" serija A, 1980, nr 2(71), s. 24-25.

15 Atsiliepimas lietuviškos draugystès „Želmuo” Paryžiuje, Tilžèje 1902, s. 11. W historiografii panuje opinia, że towarzystwo założono w 1896 r.; E. Aleksandravičius, A. Kulakauskas, op. cit., s. 324. 
z polskością. Jak pokazują pierwsze dokumenty towarzystwa, np. przyjęty w $1893 \mathrm{r}$. statut, oficjalnie równorzędne były oba języki: polski i litewski ${ }^{16}$. Choć trzeba zaznaczyć, że do 1893 r. podczas posiedzeń używany był język francuski, a później polski, jako zrozumiały dla wszystkich. Język litewski znali bowiem nieliczni członkowie towarzystwa ${ }^{17}$. W pierwszych dokumentach i statucie podkreślano, że celem towarzystwa będzie nie tylko zjednoczenie Litwinów rozrzuconych na całym terytorium Francji do wspólnych działań, ale też ochrona i rozwijanie litewskich wartości kulturowych, ojczystego języka ${ }^{18}$. Nie zapomniano też o tradycji unijnej. W ostatnim dziesięcioleciu XIX w., gdy coraz wyraźniejsza była sprzeczność między litewskimi i polskimi dążeniami etniczno-kulturowymi i etniczno-politycznymi, towarzystwo „Želmuo” było w zasadzie jedyną organizacją, która usiłowała przezwyciężyć tę sprzeczność, próbowała połączyć ostateczne cele obu ruchów.

Należy zaznaczyć, że w omawianym okresie ważnym momentem polityzacji litewskiego ruchu narodowego stało się założenie pierwszej partii politycznej - Litewskiej Partii Socjaldemokratycznej (Lietuvos socialdemokratų partija, LSDP) - oraz opracowanie w 1896 r. jej programu. Najważniejszy jego punkt zawierał formułę przyszłej litewskiej państwowości. Opierała się ona wyraźnie na tradycji państwowości byłego Wielkiego Księstwa Litewskiego w wersji unijnej i przypominała omówioną koncepcję Akielewicza. W tym punkcie programu wpisano następujące stwierdzenie: „Niezależna republika federacyjna, złożona z Litwy, Polski i innych krajów, zjednoczonych z wolnej woli” (podkr. $\mathrm{w}$ oryg. $)^{19}$. W tych założeniach wyraźnie widoczne jest dawne myślenie państwowe, które przetrwało nawet powstania listopadowe i styczniowe, trafiając do umysłów socjaldemokratów pochodzenia szlacheckiego. Notabene głównymi autorami programu byli przedstawiciele szlachty - Andrius Domaševičius ${ }^{20}$

16 Gintautas [J. Bagdonas], Paryžius (D-tė Želmuo), „Varpas” 1901, nr 4, s. 44, 45; Atsiliepimas lietuviškos draugystés „Želmuo” Paryžiuje..., s. 11-12.

17 Gintautas [J. Bagdonas], op. cit., s. 45. W 1896 r. w korespondencji pisma „Varpas” z Paryża taka sytuacja w towarzystwie została zaprezentowana jako ówczesne realia, rzecz oczywista; Kiavèys [?], Iš Parižiaus, „Varpas” 1896, nr 11, s. 169.

18 Biblioteka Polska w Paryżu, Archiwum Henryka Gierszyńskiego. Varia-Lituanie, sygn. 2739, Ustawa Towarzystwa Litewskiego „Želmuo”, 1893.

19 Programas Lietuviškos social-demokratiškos partijos, [Tilžè] 1896, s. 8-9.

20 Andrzej Domaszewicz (Andrius Jonas Domaševičius) (1865-1935) - jeden z założycieli Litewskiej Partii Socjaldemokratycznej, lekarz, pochodził z rodziny szlacheckiej. W latach 1884-1890 studiował medycynę na Uniwersytecie w Kijowie, w latach 1891-1893 odbył staż w Petersburgu. W 1893 r. osiedlił się w Wilnie, gdzie zgromadził wokół grupę socjaldemokratów. Za działalność polityczną więziony przez władze carskie, zesłany na Syberię. Powrócił w 1904 r., pracował jako lekarz pierwszej pomocy w szpitalach w Wilnie, w 1910 r. założył prywatny szpital i poliklinikę Po odejściu w 1907 r. z LSDP w 1917 r. powrócił do aktywnej działalności partyjnej. W grudniu 1918 r. wybrany do rady robotniczej w Wilnie, w 1919 r. był ludowym komisarzem ochrony zdrowia w rządzie V. Kapsukasa. Więziony przez władze polskie, w 1920 r. wyjechał do Rosji. 
i Alfonsas Moravskis ${ }^{21}$, którzy nie potrafili nawet pisać po litewsku i dlatego do tłumaczenia programu zaangażowali działających w otoczeniu liberalnego pisma „Varpas” Kazysa Griniusa, Juozasa Bagdonasa i Stasysa Matulaitisa. W rzeczywistości szlachta litewska nawet $\mathrm{w}$ warunkach ruchu socjaldemokratycznego pozostała bardzo dobrym i trwałym nosicielem tradycji państwowych. Badacze myśli politycznej dostrzegają też wpływ Polskiej Partii Socjalistycznej. Jak wskazują Vytautas Merkys ${ }^{22}$ i Arūnas Vyšniauskas ${ }^{23}$, PPS nazywała Litwą prawie cały obszar wchodzący w skład Wielkiego Księstwa Litewskiego przed I rozbiorem (z wyłączeniem Kurlandii i Łatgalii). Z kolei w programie LSDP_z 1896 r. widzimy już wyraźnie Litwę oddzielaną nie tylko od Łotwy (Kurlandii, Łatgalii), ale również od Białorusi. „Litwa - według Andriusa Domaševičiusa - była rozumiana jako gubernia kowieńska, wileńska i grodzieńska z Suwalszczyzną"24. W 1902 r. w Wilnie odbył się V Zjazd LSDP, który dokonał zmian we wcześniejszym punkcie programu z 1896 r., podnosząc znaczenie Litwy (pojawiła się nazwa Republika Litewska) w przyszłej federacji: „Uznając prawo każdego narodu do samostanowienia i podejmowania decyzji dotyczących własnego bytu, LSDP ze strony politycznej postara się stworzyć demokratyczną Republikę Litewską, sfederowaną z sąsiadującymi narodami, znajdującymi się na tym samym poziomie rozwoju społecznego i politycznego"25. Nie wymieniono krajów, w tym Polski, względem których w ówczesnym ruchu narodowym coraz bardziej zaczęła dominować otwarcie negatywna postawa.

Powstała w otoczeniu pisma „Varpas” Partia Demokratyczna Litwinów (od 1905 r. Litewska Partia Demokratyczna, Lietuvos demokratų partija, LDP) zmieniła radykalnie kierunek dążeń politycznych litewskiego ruchu narodowego.

W 1921 r. wrócił i osiedlił się w Poniewieżu, pracował jako lekarz, jeden organizatorów i przywódców Związku Zawodowego Robotników w Poniewieżu; w latach 1923-1933 kilkakrotnie aresztowany, więziony i deportowany do Smilgiai (Smilgie).

21 Alfonsas Moravskis (Alfons Morawski) (1868-1941) - jeden z założycieli LSDP, ekonomista, krajoznawca, pochodził z rodziny szlacheckiej. W latach 1887-1892 studiował na uniwersytetach w Charkowie, Kazaniu i Kijowie. W 1890 i 1892 r. więziony za działalność polityczną. W latach 1892-1893 osiedlił się w Wilnie, gdzie skupiał wokół siebie grupki socjaldemokratów. W 1897 r., by uniknąć aresztowania, wyemigrował do Szwajcarii, gdzie w 1898 r. założył Litewskie Zagraniczne Stowarzyszenie Socjaldemokratów. W 1900 r. był jednym z organizatorów Litewskiego Pawilonu na Światowej Wystawie w Paryżu. W1902 r. skończył Wyższą Szkołą Handlu w Lipsku. W 1902 r. wystąpił z LSDP. W 1906 r. pracował w redakcji czasopisma rosyjskich kadetów „Reč'”. W latach 1922-1933 profesor Uniwersytetu Litewskiego (od 1930 r. - Uniwersytetu Witolda Wielkiego).

22 V. Merkys, Lietuvos socialdemokratai ir nacionalinio išsivadavimo judejjimas (ligi 1904 m.), w: Mintys apie Lietuvos komunistu partijos kelia, Vilnius 1989, s. 10, 16.

23 A. Vyšniauskas, Sociademokratijos politine transformacija 1896 metais, w: Lietuviu atgimimo istorijos studijos, t. 3: Lietuvos valstybès idëja (XIX a. - XX a. pradžia), Vilnius 1991, s. 96-97.

${ }^{24}$ Lietuvos ypatingasis archyvas, f. 3377, ap. 38, b. 51, A. Domaševičius, LSDP pradžia. Atsiminimai parašyti po 1925 m., k. 2.

25 V susivažiavimas LSDP, „Darbininkų balsas” 1902, nr 3, s. 2. 
W projekcie jej programu z 1902 r. sformułowano zamiar uzyskania niepodległości w granicach etnicznej Litwy. Za Akielewiczem twierdzono: „Mówiąc Litwinom - Litwa, dążymy do ustanowienia takiego praktycznego ustroju dla naszego narodu, w którym Litwini mogliby sami się rządzić, nie podlegając obcym, ich wzrost kulturalny nie byłby zaś ograniczony. To może się stać dopiero po odzyskaniu przez Litwę całkowitej niezależnej od obcych narodów autonomii w granicach etnograficznych" 26 . Zarys ten jako rdzeń programu ruchu politycznego został wymieniony w Uchwale o autonomii Litwy w granicach etnicznych, wydanej przez Wielki Sejm Wileński w 1905 r. ${ }^{27}$ Po zakończeniu tego etapu w litewskim ruchu narodowym tradycja państwowości Wielkiego Księstwa Litewskiego była wykorzystywana instrumentalnie, $\mathrm{tj}$. gdy trzeba było uzasadniać prawo narodu litewskiego do samodzielności politycznej.

Rok 1905 stał się przełomowym, gdyż stopniowo zaczęto odchodzić od aktywnie omawianego jeszcze przez cały 1905 r. projektu odrodzenia Litwy historycznej (rozumianej jako zbitka etnicznej Litwy i etnicznej Białorusi), odzwierciedlającego tradycje państwowości Wielkiego Księstwa. Należy zaznaczyć, że litewscy działacze polityczni o orientacji demokratycznej przed Wielkim Sejmem Wileńskim w 1905 r., dążąc do aktualizacji kwestii „,autonomii Litwy” w otoczeniu liberalnych sił politycznych Rosji, próbowali podczas odbywających się w kwietniu-maju 1905 r. w Wilnie zjazdów „przedstawicieli narodów Litwy” godzić koncepcję Litwy etnicznej z projektem Litwy historycznej ${ }^{28}$, którego bronili demokratycznie nastawieni litewscy Polacy, wileńscy Białorusini i Żydzi ${ }^{29}$. W początkowych dyskusjach Litwini dokonywali korekt pojęcia Litwy etnicznej w kierunku projektu Litwy historycznej, mając na celu pozyskanie litewskich Polaków, wileńskich Białorusinów i Żydów, polityków o demokratycznej orientacji - krajowców - do realizacji własnych dążeń i uniknięcia konfrontacji z Białorusinami i Polakami w kwestii spuścizny historyczno-kulturowej Wielkiego Księstwa oraz przynależności Wilna (zagadnienia te podnosili działacze reprezentujący Białorusinów, przede wszystkim Iwan (Jan) Łuckiewicz). Jak już wyżej stwierdzono, w litewskim ruchu narodowym tradycje państwowości Wielkiego Księstwa pozostawały żywe,

26 Programas Lietuviu Demokratu Partijos (projektas), „Varpas” 1902, nr 12, s. 258.

27 S-lius [J. Basanavičius], Iš didžiojo Vilniaus seimo istorijos, Vilnius 1925, s. 20.

28 Szerzej o tym zob. R. Miknys, Wileńscy autonomiści i ich projekty autonomii politycznej Litwy w latach 1904-1905, „Lituano-Slavica Posnaniensia. Studia Historica” 8, 2001, s. 108-113.

29 Uczestnik obu zjazdów, wileński lekarz Antoni Kuczewski, we wspomnieniach pisanych po 20 latach wymienił nazwiska niektórych biorących w nich udział osób, podając takie: Witold Abramowicz (Wilno), Stanisław Bagiński (Wilno), Andrius Domaševičius (Wilno), [Adam] Jentys (Mińsk), Steponas Kairys (Wilno), Zygmunt Kraszewski (Wilno), [Bronisław] Krzyżanowski (Wilno), Antoni Kuczewski (Wilno), Jan Łuckiewicz (Wilno), Zygmunt Nagrodzki (Wilno), Aleksandras Narutavičius (Żmudź), Aloiza Paszkiewiczówna „Ciotka”, Jurgis Romas (Wilno), Ignacy Wirszyłło (Wilno), [?] Woźnicki (Wilno), Aleksandr Własow (Wilno), Vladimiras Zubovas (Szawle); idem, Garść wspomnień z przed lat 20, „Przegląd Wileński” 10 I 1926, s. 2-4. 
ale traktowano je instrumentalnie, do uzasadniania prawa narodu litewskiego do politycznej samodzielności.

Jako przejaw tradycji unijnej wypada odnotować również to, że w lipcu $1905 \mathrm{r}$. w Poniewieżu z inicjatywy LDP zorganizowano zebranie „Litwinów pochodzących z różnych warstw społecznych, przedstawicieli rodzin reprezentujących czysto litewskie i polskie tradycje". W pierwszych dwóch punktach uchwały podjętej na zebraniu zaznaczono: „1. Federacyjna struktura zreorganizowanej Rosji jest właściwa. 2. Do tej federacji Królestwo Polskie i Wielkie Księstwo Litewskie dołączają jako trzy samodzielne, równe sobie pod względem etnicznym i politycznym jednostki: Polska, Litwa i Białoruś z trzema sejmami prowincji: w Warszawie, Wilnie i Mińsku. Notabene Ukraina stanowi odrębną politycznie jednostkę z sejmem w Kijowie" ${ }^{30}$. Litewscy politycy nowego pokolenia bezpardonowo wykorzystywali instrumentalnie koncepcję unii również w rosyjskim dyskursie politycznym. Jak wiadomo, liberałowie rosyjscy (przyszli kadeci) w 1905 r. zorganizowali zjazd działaczy ziemstw i miast. Starając się zrealizować plany demokratyzacji i decentralizacji Rosji, próbowali w ich realizację włączyć również liberalne siły polityczne pograniczy narodowych. Dlatego jako uczestników zjazdów zapraszali przedstawicieli środowiska litewskiego i polskiego. Jedną z głównych kwestii podejmowanych na zjazdach była autonomia Polski, omawiana szczegółowo podczas piątego (12-15/21-27 września 1905 r.) $)^{31}$ oraz szóstego (6-13/18-25 listopada 1905 r.) zjazdu. Wzięli w nich udział m.in. wybrani na wspomnianym zebraniu w Poniewieżu Kazys Grinius, Vaclovas Bielskis i Povilas Višinskis. Próbowali oni poza kwestią autonomii Polski włączyć do porząadku obrad zjazdów również zagadnienie autonomii politycznej Litwy. Višinskis w zorganizowanych przez kadetów dyskusjach w sekcjach poświęconych autonomii Litwy był gotów zagrać również kartą tradycji państwowości Wielkiego Księstwa Litewskiego. Jak wskazują zachowane w archiwum zarysy przygotowanej przez niego mowy, żądanie autonomii musiało opierać się na silnej argumentacji historycznej: samodzielności Wielkiego Księstwa w ramach unii lubelskiej, ponadto nawiązywał on również do manifestu z 1795 r. przyłączenia Litwy do Rosji, zgodnie z którym, w opinii Višinskisa, „Litwie pozostawiono takie same prawa jak w przypadku wspomnianej unii" ${ }^{32}$. Można stwierdzić, że próbowano wykorzystać pogłoski, iż takie prawa potwierdził dla Litwy również kongres wiedeński ${ }^{33}$.

Ogólnie rzecz ujmując, obrana w latach 1906-1915 przez Litwinów formuła dążenia do samodzielności politycznej, oparta na podstawie etnicznej, przede wszystkim niszczyła tradycje państwowości unijnej, zmniejszając zarazem

30 P-tis [J. Vileišis], Iš Lietuvos susivažiavimų nutarimų, „Varpas” 1905, nr 7/8, s. 74-75.

31 Ibidem.

32 Lietuvių literatūros ir tautosakos instituto bibliotekos Rankraščių skyrius, f. 1-695, P. Višinskis, [Straipsnis spaudai] [tytuł nadany przez prowadzącego archiwum], k. 2.

${ }^{33}$ Ibidem. 
skuteczność tradycji państwowości Wielkiego Księstwa, wobec której nie pozostawali obojętni. Aż do wybuchu I wojny światowej w otoczeniu zarówno oficjalnym (Duma) ${ }^{34}$, jak i w nieoficjalnym (masoni - Konwent Wielkiego Wschodu Rosji) litewscy politycy popierali projekt państwowości Litwy etnicznej ${ }^{35}$. Jedynym wyjątkiem była pierwsza połowa 1915 r., gdy z inicjatywy Michała Römera, Jurgisa Šaulysa, Mykolasa Biržiški, Augustinasa Janulaitisa, Jonasa Vileišisa oraz Felicii Bortkevičiené, czyli demokratów i socjaldemokratów, przedstawiono projekt odrodzenia państwowości Litwy, wiążąc go z polskim ruchem narodowym w kwestii niepodległości. Proponowano wówczas odrodzenie idei Rzeczypospolitej jagiellońskiej w formie federacji równoprawnych, demokratycznych państw Polski i Litwy, dążąc do oderwania Litwy od Rosji ${ }^{36}$. Jednak konsultacje, które miały miejsce w Warszawie między z jednej strony reprezentującymi stronę litewską Mykolasem Sleževičiusem, Jurgisem Šaulysem, Witoldem Abramowiczem i Michałem Römerem, a z drugiej reprezentującym stronę polską blokiem niepodległościowców ${ }^{37}$ skończyły się niepowodzeniem wskutek negatywnego stanowiska Sleževičiusa ${ }^{38}$. Dla niego było nie do zaakceptowania połączenie samodzielności politycznej Litwy z niepodległością Polski.

Inny, podobny epizod również zakończył się niepowodzeniem - w latach wojny ożyło na krótko dążenie do odrodzenia państwowości Litwy historycznej w postaci Konfederacji Wielkiego Księstwa Litewskiego. Wiemy, że w grudniu 1915 r. założona w Wilnie konfederacja rozpowszechniła uniwersał głoszący chęć odrodzenia takiego państwa: „19 grudnia 1915 r. członkowie organizacji litewskich, białoruskich, polskich i żydowskich założyli Konfederację Wielkiego Księstwa Litewskiego, dążąc wspólnymi siłami do tego, by ziemie Litwy i Białorusi, kiedyś wchodzące w skład Wielkiego Księstwa Litewskiego, teraz zajęte przez wojska niemieckie, $w$ nowych warunkach historycznych stanowiły niepodzielną całość jako osobne państwo Litwa i Białoruś, w którym są zagwarantowane prawa wszystkich mniejszości narodowych, zamieszkałych na tym terytorium"39. $\mathrm{Na}$ jednym z dokumentów konfederacji, zatytułowanym „Obywatele”, podpisy złożyli ówcześni działacze litewskiego i białoruskiego ruchu narodowego oraz działacze żydowscy o orientacji demokratycznej: Jurgis Šaulys, Jonas Vileišis, Augustinas Janulaitis, Antoni Łuckiewicz, Iwan Łuckiewicz, Dominykas Semaška (Dominik

34 P. Čepenas, Naujujų laiku Lietuvos istorija, t. 1, Chicago 1977, s. 425-432.

35 LMAVB, f. 138-2230, M. Römer, Dziennik 29 XII 1912-24 I 1914, t. 3, s. 1, 16, 19-20, 40; LMAVB, f. 138-2231, M. Römer, Dziennik 25 I 1914-4 III 1915, t. 4, s. 20, 21, 253.

36 LMAVB, f. 138-2231, M. Römer, Dziennik 25 I 1914-4 III 1915, t. 4, s. 355.

37 LMAVB, f. 138-2232, M. Römer, Dziennik 5 III 1915- 21 IV 1915, t. 5, s. 6-7; S-lius [J. Basanavičius], op. cit., s. 115.

38 LMAVB, f. 138-2232, M. Römer, Dziennik 5 III 1915- 21 IV 1915, t. 5, s. 38, 45, 46.

391915 m. gruodžio mèn. atsišaukimas „Lietuvos Didžiosios Kunigaikštystès Konfederacijos Universalas", w: Lietuva vokiečiu okupacijoje Pirmojo pasaulinio karo metais 1915-1918. Lietuvos nepriklausomos valstybės genezé, oprac. E. Gimžauskas, Vilnius 2006, s. 63. 
Siemaszko), Vaclau Lastouski (Wacław Łastowski), Aleksandr Zasztowt, Cemak Szabad, Szymon Rozenbaum (Simonas Rozenbaumas) ${ }^{40}$. Jednak zarówno uniwersał, jak i sama Konfederacja Wielkiego Księstwa Litewskiego zostały rychło zapomniane przez litewskich polityków. Udział Litwinów w przygotowaniu dokumentów tej konfederacji można wyjaśnić m.in. względami taktycznymi. W taki sposób zabezpieczono się na wypadek, gdyby projekt ten spotkał się z pozytywną reakcją ze strony władz Niemiec.

Mimo wszystko, rezygnując z planów realizacji projektu Litwy historycznej jako takiej, w Akcie 16 lutego ci sami liderzy litewskiego ruchu narodowego wskazali, że opierając się na „postanowieniu Konferencji Wileńskiej Litwinów z 18-23 września 1917 r., ogłaszają odrodzenie niepodległego, opartego na podstawach demokratycznych państwa litewskiego"41. W taki sposób zadeklarowali więź z tradycją państwowości Wielkiego Księstwa. Można to różnie oceniać. Przytoczę jedną z ocen, moim zdaniem logiczną i uzasadnioną. Znakomity znawca prawa konstytucyjnego Michał Römer dość wyraźnie opowiedział się za więzami historycznymi nowoczesnego - narodowego - państwa litewskiego z Wielkim Księstwem, za sukcesją tradycji Litwy historycznej: „W moim rozumieniu jest to ciąg dalszy naszej niepodległej Litwy. (To nie to samo, co Francja, Hiszpania, Wielka Brytania czy nawet Polska)"42. W zasadzie należy zgodzić się

${ }^{40}$ Lietuvos centrinis valstybès archyvas, f. 383, ap. 7, b. 56, k. 53.

41 Vasario 16-osios Lietuvos nepriklausomybès aktas, w: Lietuva vokiečiu okupacijoje..., s. 285. Trzeba zaznaczyć, że wzmianka w Akcie 16 lutego: „ogłaszają odrodzenie niepodległego, opartego na podstawach demokratycznych państwa litewskiego" była wpisana pod wymogiem (dymisji z Rady Litewskiej) Mykolasa Biržyški, Steponasa Kairysa, Petrasa Klimasa, Jonasa Vileišisa. Taka formuła dawała możliwość wspólnej państwowości zarówno dla Litwy, jak i Białorusi. I nie jest to przypadek. Wiadomo, że S. Kairys był w gronie działaczy obecnych na wiecu 16 IX 1917 r. w Wilnie, którzy przyjęli rezolucję: „Zebrani na wiecu dn. 16 września 1917 r. w sali Klubu Robotniczego przedstawiciele socjalistycznych i demokratycznych sfer narodowości polskiej, litewskiej, białoruskiej i żydowskiej, przyjęli następującą rezolucję w sprawie przyszłości Litwy: Zebrani wychodzą z głębokiego przeświadczenia, że jedynie polityczne uniezależnienie się Litwy i ukształtowanie jej stosunków wewnętrznych na podstawach szczerze demokratycznych, w stanie jest podźwignąć kraj nasz z upadku i zapewnić mu w przyszłości najlepsze warunki do rozwoju jego sił wytwórczych, do podniesienia dobrobytu, do należytego zaspokojenia potrzeb narodowo-kulturalnych wszystkich narodowości Litwę zamieszkujących - Polaków, Litwinów, Białorusinów i Żydów. Zebrani także z całą stanowczością zaznaczają, że decydować o przyszłym losie Litwy, jej urządzeniu wewnętrznem, jej stosunku do państw ościennych i podstawach spółżycia z krajami sąsiedniemi, powołana jest jedynie konstytuanta Litwy, swobodnie obrana przez całą ludność ziem litewsko-białoruskich bez różnicy narodowości, wyznania i płci, powszechnym, równym, bezpośrednim i proporcjonalnym głosowaniem. Zebrani zanoszą kategoryczny protest przeciwko wszelkim próbom uzurpowania naczelnych praw przedstawicielstwa kraju - jego sejmu ustawodawczego - skądby one nie pochodziły”; A. Szklennik, „Wspomnienia o wydarzeniach $w$ Wilnie i w kraju": dziennik, cz. 2, wstęp i oprac. J. Gierowska-Kałłaur, Warszawa 2019 (Metamorfozy Społeczne, t. 18), zapis z 16 IX 1917 r., s. 367-371.

42 M. Römeris, Lietuvos konstitucines teisés paskaitos, cz. 1, Kaunas 1937, s. 19. 
z komentarzem historyka Česlovasa Laurinavičiusa, że Römer niepodległą Litwę uznawał za państwo, które zerwało więzi z tradycją obywatelską Wielkiego Księstwa, tzn. kształtujące nową tradycję. Natomiast w kwestii Polski Römer uważał, że w większym lub mniejszym stopniu udało się jej nawiązać do przeszłości, dlatego popierało ją wielu wychowanków tradycji Litwy historycznej ${ }^{43}$. Jednak należy zauważyć, że Römer w całości nie odrzucał roszczeń nowoczesnej Litwy do bycia kontynuatorką Wielkiego Księstwa. Podkreślając, że litewskie odrodzenie narodowe miało historyczne ambicje kontynuacji i „niebudowania Litwy jako nowego dzieła, ale akurat jego odbudowania, ożywienia”, jako jeden z przejawów takich ambicji wskazał „żądanie stolicy Litwy historycznej Wilna, połączenie z odbudową polityczną Litwy" ${ }^{4}$. Wilno traktował jako najważniejszy i podstawowy łącznik nowoczesnej Litwy z Litwą historyczną, i dlatego walce o jego odzyskanie nadawał głębokie polityczne, szczególnie geopolityczne, znaczenie. $\mathrm{Z}$ drugiej strony, był też przekonany, że kształtowany przez Litwinów organizm państwowy jest żywym przykładem, jak należy w państwie łączyć i organizować ziemie wchodzące w skład byłego Wielkiego Księstwa ${ }^{45}$. Uważał, że wyłącznie „młode państwo, tworzone przez Litwinów na ziemiach byłego Wielkiego Księstwa jest pierwszym wyraźnym symbolem stworzonym przez budzące się masy ludzkie [...]. Nie Rosja, i nie Niemcy czy Polska - ale ono..."46. Według niego „faktyczna siła litewskiego ruchu narodowego w stosunkach z innymi oddziałującymi na to terytorium siłami narodowymi" decydowała o konkretnej budowie litewskiego państwa narodowego ${ }^{47}$.

Podsumowując, sformułuję kilka tez, na podstawie których będzie można kontynuować badania wyjaśniające wpływ unii na kształtowanie się i rozwój litewskiego federalizmu. Po pierwsze, mówiąc o Wielkim Księstwie Litewskim po 1569 r., trzeba chcąc nie chcąc, pamiętać również o unii w postaci Rzeczypospolitej Obojga Narodów. Po drugie, negowanie unii bez odrzucenia Wielkiego Księstwa nie może zostać sprowadzone do rezygnacji z modernizacji tradycji państwowości Rzeczypospolitej Obojga Narodów. Przejawiała się ona w terminach dotyczących federacji, konfederacji, używanych w retoryce litewskich polityków oraz projekcjach państwowości Litwy w końcu XIX i na początku XX w. Po trzecie wreszcie, oczywiste jest, że w badaniach nad litewskim ruchem narodowym, zwłaszcza rozwojem nowoczesnego społeczeństwa, koniecznie należy unikać metodologii

43 Č. Laurinavičius, Mykolas Römeris - Lietuvai, arba dar karta apie Lietuvos pilietinio paveldo problema, „Kultūros barai” 1995, nr 2, s. 55.

${ }^{44}$ LMAVB, f. 138-2265, M. Römeris, Kad Vilniaus problema yra viena svarbiausiųjų..., rkps nieukończonego artykułu, s. 2-3.

45 M. Römer, Proces odrodzeniowy narodu litewskiego i jego rezultaty, „Nowe Słowo” 1940, nr 38, s. 1-2; idem, Naiwni, „Głos Litwy” 1920, nr 2, s. 2-3.

46 LMAVB, f. 138-2252, M. Römer, Dziennik, t. 26, s. 447.

${ }^{47}$ M. Römeris, Valstybè, t. 2, Kaunas 1935, s. 234. 
nacjonalistycznej i jeszcze śmielej niż dotychczas rozwijać badania w paradygmacie ponadnarodowych studiów historycznych. Na Litwę należy spoglądać przede wszystkim jako nieodłączny element Europy Środkowo-Wschodniej.

\section{Streszczenie}

W artykule podjęto próbę krytycznej oceny tezy funkcjonującej w historiografii litewskiej, a częściowo także polskiej, że idea unii obu państw została wyeliminowana z projektów litewskiego ruchu narodowego ukształtowanych w końcu XIX i na początku XX w. Wyniki analizy ukazują potrzebę badań koncepcji federalizmu litewskiego, ze szczególnym uwzględnieniem kwestii wpływu na nią unii polsko-litewskiej. W litewskiej myśli politycznej występowały nurty wskazujące na konieczność włączenia tradycji państwowości Wielkiego Księstwa Litewskiego także po 1569 aż do 1795 r. w projekty nowoczesnej Litwy, co uwidaczniają odnoszące się do niej koncepcje federalistyczne i konfederacyjne. Metodologia nacjonalistyczna była w litewskiej historiografii przeszkodą w dostrzeganiu roli idei unijnej w konstrukcji państwowości nowoczesnej Litwy.

\section{Was the Union Really Erased from the Modern Lithuanian Statehood Projects in the Late Nineteenth - Early Twentieth Centuries Summary}

The article offers a critical assessment of the deeply entrenched view in Lithuanian and Polish historiography that the idea of the (Lublin) Union was erased from the Lithuanian statehood projects created within the Lithuanian national movement in the late nineteenth-early twentieth centuries. Summarising the critical assessments made against this idea, several theses were formulated based on which further research could be conducted that could explain the effects of the Union on the formation and development of "Lithuanian federalism". (1) In terms of the Grand Duchy of Lithuania after 1569, like it or not, the Union in its semblance as the Polish-Lithuanian Commonwealth should also be acknowledged. (2) The Union's denial without taking the GDL into account cannot be reduced to a rejection of the modernisation of the PLC statehood tradition. It was expressed in the federation and confederation terminology used in Lithuanian politicians' rhetoric and projections of Lithuanian statehood at the end of the nineteenth-early twentieth centuries. (3) It is obvious that in research on the Lithuanian national movement, especially concerning the evolution of modern society, nationalism methodology must be avoided, and such research should be developed in a much bolder way within the transnational historical research paradigm. The case of Lithuania should firstly be looked at as a phenomenon of the Central East European region.

\section{Bibliografia}

\section{Źródła rękopiśmienne}

Biblioteka im. Wróblewskich Litewskiej Akademii Nauk w Wilnie, Dział Rękopisów (LMAVB), f. 138-2230; f. 138-2231; f. 138-2232; f. 138-2252; f. 138-2265. 
Biblioteka Polska w Paryżu, Archiwum Henryka Gierszyńskiego. Varia-Lituanie, sygn. 2739.

Lietuvos centrinis valstybès archyvas, f. 383, ap. 7, b. 56.

Lietuvos ypatingasis archyvas, f. 3377, ap. 38, b. 51.

Lietuvių literatūros ir tautosakos instituto bibliotekos Rankraščiu skyrius, f. 1-695.

\section{Źródła drukowane}

Atsiliepimas lietuviškos draugystès „Želmuo” Paryžiuje, Tilžèje 1902.

Lietuva vokiečiu okupacijoje Pirmojo pasaulinio karo metais 1915-1918. Lietuvos nepriklausomos valstybès genezè, oprac. E. Gimžauskas, Vilnius 2006.

Lietuvių kultūros veikèjų laiškai J.I. Kraševskiui, wyd. B. Genzelis, Vilnius 1992.

Litwa wobec wojny. Poufny memoriat Michała Römera z sierpnia 1915, oprac. W. Sukiennicki, „Zeszyty Historyczne” 1970, 17, s. 56-127.

Programas Lietuviškos social-demokratiškos partijos, [Tilžè] 1896.

Szklennik A., „Wspomnienia o wydarzeniach w Wilnie i w kraju”: dziennik, cz. 2, wstęp i oprac. J. Gierowska-Kałłaur, Warszawa 2019 (Metamorfozy Społeczne, t. 18).

\section{Prasa}

„Darbininkų balsas” 1902, nr 3.

„Varpas” 1896, nr 11; 1901, nr 4; 1902, nr 12; 1905, nr 7/8.

\section{Opracowania}

Aleksandravičius E., Unijos šešèlyje, arba federalizmas lietuviu Atgimimo politinèje vaizduotèje (XIX a. pabaiga - XX a. pradžia), w: Lietuva ir Lenkija XX amžiaus geopolitinèje vaizduotèje, Kaunas 2012, s. 11-33.

Aleksandravičius E., Kulakauskas A., Carų valdžioje. Lietuva XIX amžiuje, Vilnius 1996 (wyd. pol.: Pod władza carów. Litwa w XIX wieku, tłum. B. Kalęba, Kraków 2003).

Bardach J., Krajowcy, federaliści, inkorporacjoniści, w: idem, O dawnej i niedawnej Litwie, Warszawa 1988.

Borejsza J., Emigracja polska po powstaniu styczniowym, Warszawa 1966.

Čepenas P., Naujujų laiku Lietuvos istorija, t. 1, Chicago 1977.

Grygaitis K., Polskie idee federacyjne i ich realizacja w XIX i XX w., Częstochowa 2001.

Jurkiewicz J., Demokraci wileńscy w latach 1905-1914 (Zarys działalności politycznej), „Acta Baltico-Slavica" 18, 1983, s. 157-173.

Jurkiewicz J., Rozwój polskiej myśli politycznej na Litwie i Białorusi w latach 1905-1922, Poznań 1983.

Krajowość - tradycje zgody narodów $w$ dobie nacjonalizmów. Materiaty z międzynarodowej konferencji naukowej w Instytucie Historii UAM w Poznaniu (11-12 maja 1998), red. J. Jurkiewicz, Poznań 1999.

Kudirka J., Mikalojaus Akelaičio (1829-1887) socialinès pažiūros, „Lietuvos aukštụjų mokyklų mokslo darbai" serija A, 1980, nr 2(71), s. 15-27.

Laurinavičius Č., Mykolas Römeris - Lietuvai, arba dar karta apie Lietuvos pilietinio paveldo problemą, „Kultūros barai” 1995, nr 2, s. 54-59.

Lewandowski J., Federalizm. Litwa i Białoruś w polityce obozu belwederskiego (XI 1918 - IV 1920), Warszawa 1962. 
Lietuvos istorija, t. 10, cz. 1: Nepriklausomybè (1918-1940), red. Č. Laurinavičius, Vilnius 2013.

Łossowski P., Dwie drogi odrodzenia kulturalnego i narodowego Litwinów (Baranauskas i Basanavičius), „Studia z Dziejów Rosji i Europy Środkowo-Wschodniej” 31, 1996, s. 149-155.

Łossowski P., Po tej i tamtej stronie Niemna. Stosunki polsko-litewskie 1883-1939, Warszawa 1985.

Merkys V., Lietuvos socialdemokratai ir nacionalinio išsivadavimo judejimas (ligi 1904 m.), w: Mintys apie Lietuvos komunistu partijos kelia, Vilnius 1989, s. 9-19.

Miknys R., Lietuvos Didžiosios Kunigaikštystès valstybingumo tradicija lietuvių tautinio judejimo programoje: teorinis ir praktinis aspektai, w: Lietuvos Didžiosios Kunigaikštijos tradicija ir tautiniai naratyvai, oprac. A. Bumblauskas, G. Potašenko, Vilnius 2009, s. 117-143.

Miknys R., Mykolo Römerio Lietuvos valstybingumo koncepcija ir pastangos ja igyvendinti 1911-1919 metais, w: Lietuviu atgimimo istorijos studijos, t. 13: Mykolas Römeris, Vilnius 1996, s. 88-113.

Miknys R., Wileńscy autonomiści i ich projekty autonomii politycznej Litwy w latach 1904-1905, „Lituano-Slavica Posnaniensia. Studia Historica” 8, 2001, s. 98-113.

Ochmański J., Historia Litwy, Wrocław 1982.

Ochmański J., Litewski ruch narodowo-kulturalny w XX wieku, Białystok 1965.

Römer M., Naiwni, „Głos Litwy” 1920, nr 2, s. 2-3.

Römer M., Proces odrodzeniowy narodu litewskiego i jego rezultaty, „Nowe Słowo” 1940, nr 38, s. 1-2.

Römeris M., Lietuvos konstitucinés teisés paskaitos, cz. 1, Kaunas 1937.

Römeris M., Valstybè, t. 2, Kaunas 1935.

Sawicki J., Michał Römer a problemy narodowościowe na ziemiach byłego Wielkiego Księstwa Litewskiego, Toruń 1998.

Sirutavičius V., Dvi lietuviu tautinio atgimimo interpetacijos (Mykolas Römeris ir Juozapas Albinas Herbačiauskas), w: Lietuviu atgimimo istorijos studijos, t. 13: Mykolas Römeris, Vilnius 1996, s. 54-79.

Solak Z., Między Polską a Litwą. Życie i działalność Michała Römera 1880-1920, Kraków 2004.

Tyla A., Связи Микалоюса Акелачтиса с польскими культурными и политическими деятелями / Svîazi Mikaloiusa Akelaitisa s pol'skimi kul'turnymi i politycheskimi deiâteliami, w: Zwiazki rewolucjonistów polskich i rosyjskich $w$ XIX w. Materiały sesji naukowej Poznań, 12-14 listopada 1970, przyg. W. Śliwowska, Wrocław 1972, s. 171-179.

Vyšniauskas A., Sociademokratijos politine transformacija 1896 metais, w: Lietuviu atgimimo istorijos studijos, t. 3: Lietuvos valstybès ideja (XIX a. - XX a. pradžia), Vilnius 1991, s. 67-132.

Rimantas Miknys - dr, pracownik naukowy Instytutu Historii Litwy, profesor Uniwersytetu Witolda Wielkiego w Kownie i Uniwersytetu Kłajpedzkiego. Zainteresowanie badawcze: historia polityki, kultury, mentalności i idei w XIX i pierwszej połowie XX w. E-mail: rimantas.miknys@gmail.com 